\title{
Sensitivitas Skema Mikrofisik Awan pada Model WRF untuk Simulasi Hujan Deras di Purworejo Jawa Tengah 20 Desember 2013
}

\author{
Fitria Puspita Sari* \\ Pelayanan Jasa, Balai Besar Badan Meteorologi, Klimatologi, dan Geofisika (MKG) \\ Wilayah III Denpasar, Jl. Raya Tuban-Badung, Denpasar, 80361
}

Intisari

\begin{abstract}
Pada tanggal 20 Desember 2013 pukul 03.00 WIB (19 Desember 2013 20.00 UTC) terdapat banjir di Kabupaten Purworejo. Banjir yang diakibatkan hujan deras dan angin kencang tersebut juga membawa dampak kerugian materiil dan bahkan memakan korban jiwa. Lokasi yang cukup jauh dari stasiun operasional BMKG membuat kejadian tersebut sulit untuk didapatkan data observasinya, sehingga digunakan model WRF untuk simulasi kejadian. Dalam simulasi ini digunakan skema mikrosfisik awan yang berbeda untuk mengetahui sesnsitivitas penggunaan parameterisasi ini dalam setting konfigurasi model WRF. Secara keseluruhan peneliti berhasil melakukan simulasi mengenai adanya kemungkinan pertumbuhan awan konvektif penghasil hujan. Penggunaan skema mikrofisik awan ternyata berpengaruh terhadap hasil model, dimana skema Morrison-2 dianggap paling baik saat simulasi kejadian banjir Purworejo. Namun model tidak cukup mampu merepresentasikan intensitas hujan dan waktu terjadinya dengan sesuai, sebab model menghasilkan nilai hujan yang cenderung rendah (underestimate) dan menghasilkan hujan pada waktu yang lebih lama. Jadi penulis menyimpulkan bahwa model hanya mampu mensimulasikan adanya pertumbuhan awan konfektif dan tidak untuk menghasilkan hujan.
\end{abstract}

\begin{abstract}
On $20^{t h}$ December 2013 03.00 LT (19 ${ }^{t h}$ December 2013 20.00 UTC) there was a flood at Purworejo regency. The flood caused by heavy rain and strong winds gave bad impact like property's disadvantage and human victims. Place of the accident is rather far from meteorology office BMKG, being hard for getting the observation's date. So, it needs WRF model to simulate. In this simulation the difference microphysics scheme to know the sensitivity of this scheme at WRF's configuration setting has been used. The whole simulation result is successful to identify the presistence of convective cloud that produce rain. The using of microphysics scheme influences the model's result. Morrison-2 is judged being a best scheme when it is used on the simulation of Purworejo's flood. But, the model cannot represent intensity of rain and its time exactly, because WRF produces rain that intensity is low (underestimate) and it needs more time. Finally we know that the model is only able to simulate the development of convectif cloud, not to produce rain.
\end{abstract}

KATA KUNCI: Flood, heavy rain, WRF model, microphysics cloud scheme

\section{PENDAHULUAN}

Menurut data pantauan yang didapat dari www.bnpb.go.id [1], tanggal 20 Desember 2013 pukul 03.00 WIB atau 19 Desember 201320.00 UTC terdapat banjir di Kabupaten Purworejo, Jawa Tengah. Banjir tersebut hampir merendam sebagian besar kecamatan di kabupaten tersebut, diantaranya Kec. Kaligesing, Kec. Gebang, Kec. Purworejo, Kec. Pitaruh, Kec. Bruno, Kec. Kutoarjo, Kec. Ngombol, Kec. Bagelan, dan yang paling parah Kec. Butuh dengan 2273 jiwa mengungsi. Banjir yang diakibatkan hujan deras dan angin kencang tersebut juga membawa dampak kerugian materiil dan bahkan memakan korban jiwa.

*E-MAIL: pheesajjoh@gmail.com; fitria.puspita@bmkg.go. id

(C) Jurusan Fisika FMIPA ITS
Kabupaten Purworejo terletak pada posisi $109,79^{\circ}$ $110,14^{\circ} \mathrm{BT}$ dan $7,5^{\circ}-7,9^{\circ} \mathrm{LS}$. Lokasi yang cukup jauh dari stasiun operasional BMKG membuat kejadian tersebut sulit untuk didapatkan data observasinya, ditambah lagi menurut Ridzkiana [2], kondisi fisis atmosfer pada daerah tropis sangat tidak menentu yang mengakibatkan kesulitan simulasi cuaca pada daerah tropis. Oleh sebab itu dibutuhkan metode simulasi cuaca skala meso yang mampu mendekati kondisi atmosfer sebenarnya. Dalam penelitian ini digunakan model simulasi numerik WRF-ARW (The Advanced Research-Weather Research and Forecasting).

WRF merupakan model numerik yang memuat beberapa skema paramaterisasi, salah satunya skema mikrofisik. Menurut Rajeevan [3] proses mikrofisik awan memiliki peran penting dalam memberikan pengaruh secara langsung pada kolam-kolam dingin (karena evaporasi hujan) dan pemanasan laten (karena kondensasi). Sehingga parameterisasi mikrofisik dapat dijadikan sumber rujukan dari ketidakpas- 


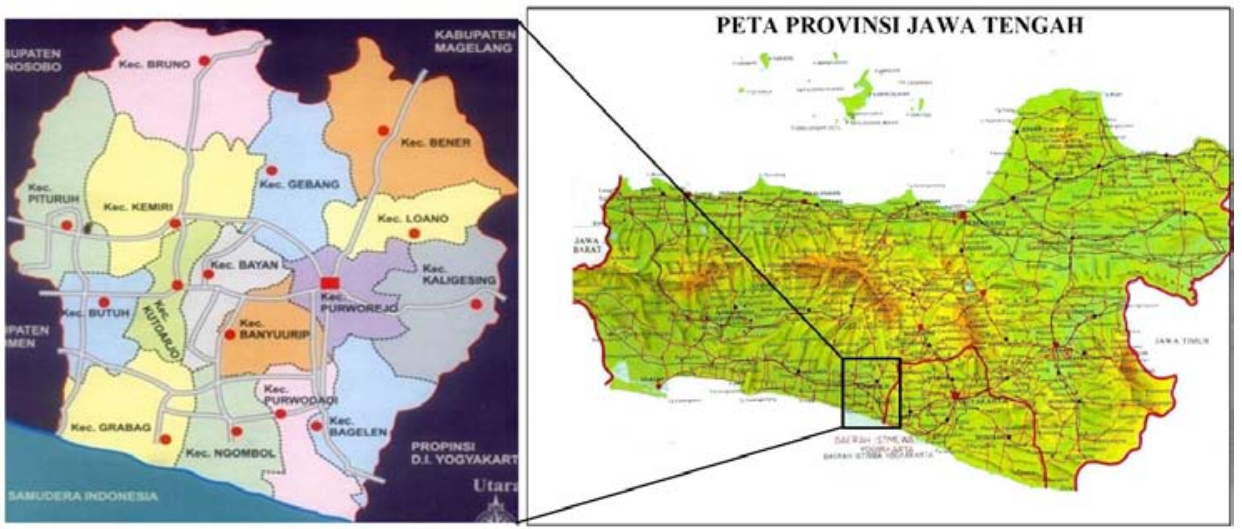

Gambar 1: Peta lokasi penelitian ([4])

tian konveksi pada model prediksi cuaca resolusi tinggi. Parameterisasi tersebut penting untuk menaksir cuaca secara meningkat berdasar sifat fisik dari awan sehingga dalam pembuatan prediksi diharapkan memberikan hasil lebih baik. Selain itu penaksiran skema mikrofisik awan tidak hanya dijadikan sebuah praktik signifikan, melainkan juga sebagai pemandu yang berguna untuk pengembangan parameterisasi mikrofisik awan selanjutnya.

Tujuan dari penelitian ini selain untuk mengetahui keadaan ketika kejadian dilihat dari sisi meteorologinya, juga untuk mengetahui seberapa mampu skema mikrofisik pada model WRF dijadikan rujukan untuk simulasi kejadian banjir tersebut. Namun perlu diketahui bahwa objek dari penelitian ini lebih untuk mengetahui perbandingan penggunaan skema mikrofisik awan yang berbeda untuk simulasi hujan deras, bukan untuk menemukan skema mikrofisik awan mana yang lebih mendekati observasi. Peta lokasi penelitian ditunjukkan dalam Gambar 1.

\section{KAJIAN PUSTAKA}

\section{A. Weather Research and Forecasting (WRF)}

Model WRF-ARW ini dikembangkan oleh NCAR ( $\mathrm{Na}$ tional Center for Atmospheric Research) yang bekerjasama dengan National Centers for Environmental Prediction (NCEP) Colorado USA, Forecast System Laboratory of the NOAA (NOAA/FSL), Air Force Weather Agency (AFWA) serta instansi lainnya dengan versi pertamanya WRF versi 1.0 yang di-release Desember 2000 [5].

Namun tidak semua proses di atmosfer bisa diselesaikan secara eksplisit dari persamaan gerak pada model numerik. Ada proses-proses di atmosfer yang memiliki skala spasial dan temporal lebih kecil dari skala grid dari model (subgrid). Sehingga dalam setiap model NWP terdapat parameterisasi terhadap parameter cuaca yang perhitungannya tidak bisa dilakukan langsung dengan suatu rumusan matematis [6]. Skema-skema parameterisasi ini mencoba membuat simulasi seperti kondisi nyata. Salah satu parameterisasi yang terdapat dalam model WRF-ARW adalah parameterisasi mikrofisik.

\section{B. Parameterisasi mikrofisik awan (mp_physics)}

Menurut Hadi [7], mikrofisis melibatkan uap air, awan, dan proses presipitasi secara eksplisit. Dalam ARW versi terbaru, mikrofisis dibawa pada akhir dari time-step sebagai proses penyelesaian. Alasannya, adalah bahwa penyelesaian kondensasi harus dilakukan di akhir time-step untuk menjamin bahwa keseimbangan jenuh akhir cukup akurat untuk memperbaharui temperatur dan kelembaban. Namun, merupakan hal yang penting juga untuk memiliki panas laten agar dapat menekan temperataur potensial selama sub-step dinamis. Hal ini dilakukan dengan menyimpan pemanasan mikrofisis sebagai sebuah perkiraan untuk time-step selanjutnya. Baru-baru ini, proses sedimentasi dihitung di dalam modul individual mikrofisis, dan untuk mencegah ketidakstabilan dalam perhitungan fluks vertikal dari presipitasi, timestep yang lebih boler dipergunakan. Penyelesaian kejenuhan juga dimasukkan ke dalam mikrofisis.

Adapun jenis skema mikrofisis yang dipakai pada penelitian ini antara lain:

1. Skema WRF Single Moment 3-Class (WSM3)

Skema WSM3 merupakan skema untuk parameterisasi mikrofisik setting default. Skema WSM3 meliputi sedimentasi es dan parameterisasi baru fase es lainnya. Perbedaan utamanya adalah digunakannya relasi diagnostik untuk jumlah konsentrasi es yang didasarkan pada kandungan massa es bukan pada temperatur. Proses pembekuan/peleburan dihitung selama fall-term sub-step untuk meningkatkan akurasi di profil pemanasan vertikal dari proses-proses ini. Urutan dari proses-proses ini juga dioptimasi untuk menurunkan sensitivitas skema terhadap langkah waktu dari model. Skema WSM3 memprediksikan tiga kategori hidrometeor, uap, hujan/es, dan hujan/salju, yang disebut juga skema es sederhana. Skema ini efisien secara komputasi untuk pemasukan proses-proses pertumbuhan es, namun kurang dalam air kelewat dingin dan nilai peleburan bertahap. Skema ini cocok untuk ukuran grid skala meso. 


\section{Skema NEW ETA FERRIER GCP}

Dikenal dengan nama skema EGCP01 atau Eta Ferrier. Skema ini memprediksikan perubahan di uap air dan kondensasi dalam bentuk tetes awan, hujan, kristal es, dan presipitasi es (salju/graupel/sleet). Medanmedan individual hidrometeor dikombinasikan ke total kondensasi. Uap air dan total kondensasi inilah yang berpengaruh dalam model. Simpanan lokal array menahan informasi prakiraan pertama yang mengesktrak kontribusi dari tetes hujan, hujan, kristal es, dan presipitasi es dari densitas variabel dalam bentuk salju, graupel, atau sleet. Densitas dari presipitasi es diestimasikan dari sebuah array lokal yang menyimpan informasi di pertumbuhan total es oleh deposisi uap dan pertumbuhan air liquid. Sedimentasi dilakukan dengan memisahkan time-averaged flux dari presipitasi ke dalam sebuah kotak grid anata penyimpanan lokal dalam kotak dan jatuh melalui dasar kotak. Hal ini muncul bersamaan dengan modifikasi dalam perlakuan proses-proses mikrofisik yang acak, mengizinkan langkah waktu yang besar untuk digunakan dengan menghasilkan hasil yang stabil. Prosesproses fase percampuran dipertimbangkan pada temperatur yang lebih hangat dari $-30^{\circ} \mathrm{C}$, padahal jenuhnya es diasumsikan untuk kondisi berawan pada temperatur yang lebih dingin.

3. Skema Morrison 2-Moment

Pada skema ini enam jenis air dimasukkan, diantaranya uap, tetes awan, kristal es, hujan, salju, dan graupel/hail. Kodenya memiliki sebuah user-specified switch untuk memasukkan baik graupel atau hail. Variabel prognostik meliputi jumlah konsentrasi dan mixing ratio dari kristal es, hujan, salju, dan grauple/hail, serta mixing ratio dari tetes awan dan uap air (total 10 variabel). Prediksi dari 2 moment (jumlah konsentrasi dan mixing ratio) membolehkan perlakuan yang lebih kasar untuk distribusi ukuran partikel, yang merupakan kunci dalam perhitungan nilai-nilai prosesproses mikrofisis dan evolusi awan/presipitasi. Beberapa liquid, es dan proses-proses fase percampuran dili-

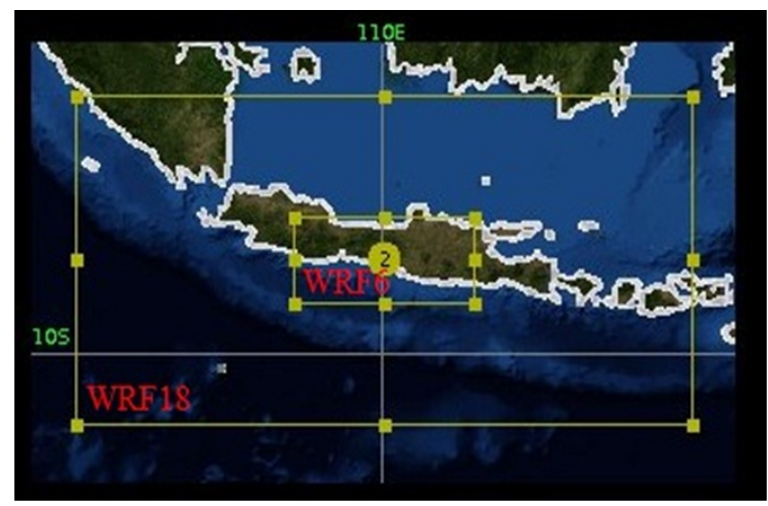

Gambar 2: Setting domain menggunakan Domian Wizard pada proses WPS
TABEL I: Spesifikasi hardware yang di pakai untuk pengolahan data.

\begin{tabular}{ll} 
MERK dan TYPE & Acer 4736 \\
PROCESSOR & Intel Core TM2 Duo processor T6600 \\
RAM SYSTEM & 1 GB Memory \\
OS & Linux Fedora 14 pada VMware Player \\
Waktu running & 3-7 jam tiap skema \\
\hline \hline
\end{tabular}

batkan. Distribusi ukuran partikel ditentukan dengan menggunakan fungsi gamma, dengan paramater intercept dan kemiringan yang berhubungan, yang didapatkan dari hasil prediksi mixing ratio dan jumlah konsentrasi. Skema ini telah diuji dengan beberapa studi kasus yang mencakup berbagi kondisi dengan cakupan yang luas.

\section{DATA DAN METODE}

\section{A. Data}

\section{Data input model}

Initial dan boundary condition dari model digunakan data FNL (Final Analysis) tanggal 18 Desember 2013 pukul 18:00 UTC sampai dengan 20 Desember 2013 pukul 12:00 UTC yang dapat dikases pada http://rda.ucaredu. [8] Data FNL ini memiliki resolusi spasial $1^{\circ} \times 1^{\circ}(111 \mathrm{~km})$ dan resolusi temporal $6 \mathrm{jam}$. Adapun panjang data yang digunakan dalam simulasi kejadian adalah 42 jam, dengan 12 jam untuk spinup time dan 30 jam berikutnya untuk periode analisa simulasi kejadian.

\section{Data dukung output}

Sebagai data dukung untuk memperkuat adanya kejadian hujan deras, digunakan data satelit yang diolah menggunakan SATAID untuk mendapat temperatur puncak awan. Adapun data mentah dapat diakses pada http://satelit.bmkg.go.id. [9].

\section{B. Metode}

Proses running model WRF menggunakan seperangkat laptop dengan spesifikasi yang dijelaskan pada Tabel I. Kemudian penelitian dilanjutkan dengan penentuan lokasi kejadian yang menjadi domain pada proses WRF Processing System (WPS) dengan center point pada $110,1^{\circ} \mathrm{BT} ; 7,7^{\circ} \mathrm{LS}$, dimana domain pertama memiliki resolusi $18 \mathrm{~km}$ (WRF18) dengan batas $101.995^{\circ}-118,005^{\circ} \mathrm{BT} ; 11,565^{\circ}-3,79947^{\circ} \mathrm{LS}$, sedang domain kedua memiliki resolusi $6 \mathrm{~km}$ (WRF6) dengan batas $107,658^{\circ}-112,342^{\circ}$ BT; $8,7241^{\circ}-6,67343^{\circ}$ LS. Pada proses WPS, digunakan WRF Domain Wizard untuk mempermudah 
TABEL II: Konfigurasi ARW-WRF.

\begin{tabular}{lll}
\hline \hline Pengaturan & & K E T E R A N G A N \\
Running WRF & DOMAIN 1 (WRF 18) & DOMAIN 2 (WRF 6) \\
\hline \multirow{2}{*}{ history_interval } & 180 detik & 60 detik \\
time_step & 90 detik & 90 detik \\
e_we & 100 & 88 \\
e_sn & 50 & 40 \\
ra_sw_physics & Dudhi scheme (1) & Dudhi scheme (1) \\
bl_pbl_physics & YSU scheme (1) & YSU scheme (1) \\
cu_physics & Kain-Fritsch (new Eta) schme (1) & Kain-Fritsch (new Eta) schme (1) \\
mp_physics & No Scheme (0) & No Scheme (0) \\
& WSM3-class simple ice schme (3) & WSM3-class simple ice schme (3) \\
& Ferrier (new Eta) scheme microphysics (5) & Ferrier (new Eta) scheme microphysics (5) \\
& Morrison 2-moment scheme (10) & Morrison 2-moment scheme (10) \\
\hline \hline
\end{tabular}

dalam penentuan domain, pembuatan namelist secara otomatis, dan menjalankan WPS (geogrid.exe, ungrib.exe, dan metgrid.exe) secara otomatis. Sehingga seluruh output dari WRF Domain Wizard ini dapat langsung digunakan untuk running model WRF. Setting domain menggunakan Domian Wizard pada proses WPS ditunjukkan Gambar 2.

Selanjutnya dilakukan proses running WRF (real.exe dan wrf.exe) dengan konfigurasi seperti ditunjukkan Tabel II. Selain pengaturan mikrofisik, skema parameterisasi lainnya merupakan setting default yakni Dudhi scheme untuk skema radiasi gelombang panjang berdasarkan integrasi sederhana yang efisien diterapkan untuk absorpsi dan hamburan pada udara cerah dan berawan. Skema Lapisan Batas (PBL) YSU scheme untuk mengurangi efek percampuran non lokal serta memasukkan fluks entrainment eksplisit dari panas, kelembaban dan momentum, serta perbedaan ketinggian spesifikasi PBL, dan skema parameterisasi Cumulus Kain-Fritsch (new Eta) yang didasarkan pada perhitungan CAPE.

Kemudian setelah didapat hasil output WRF, dilanjutkan dengan post processing pada ARWPost untuk mendapatkan output data yang dapat di display pada program Grads. Hasil dari Grads inilah yang merupakan bahan untuk analisis. Adapun rangkaian proses penelitian dapat dilihat pada diagram alir seperti ditunjukkan Gambar 3.

\section{ANALISIS DAN PEMBAHASAN}

\section{A. Observasi menggunakan Multifunctional Transport Satellite (MTSAT)}

Sebagai data dukung observasi digunakan data satelit MTSAT untuk mengetahui bahwa pada sekitar jam kejadian memang terdapat hujan. Adanya hujan erat kaitannya dengan keberadaan awan, sehingga data satelit digunakan untuk mengetahui ada tidaknya awan serta jenis awan berdasar temperatur puncak awan yang tertangkap sensor satelit. Oleh karena kejadian banjir tersebut pada dini hari, maka digunakan kanal infrared (IR-2). Menurut Pedoman Operasioanl Citra Satelit BMKG [10], daerah pertumbuhan awan-awan konvektif padat (dense-cloud) atau awan Cumulonimbus $(\mathrm{Cb})$ pada citra

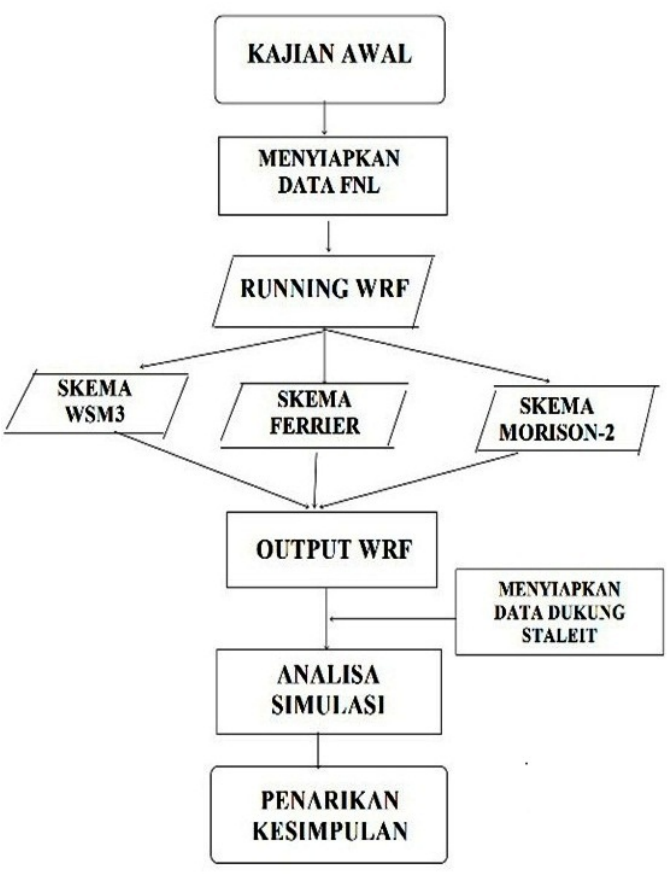

Gambar 3: Digram Alir Proses Penelitian satelit diidentifikasi dengan terlihatnya temperatur puncak awan (brightness temperature) $\leq-50^{\circ} \mathrm{C}(223 \mathrm{~K})$.

Gambar 4(a) menunjukkan adanya awan dengan temperatur puncak sekitar $-40^{\circ} \mathrm{C}$ sampai dengan $-60^{\circ} \mathrm{C}$ di bagian timur Kab. Purworejo atau sekitar Kec. Butuh yang merupakan lokasi banjir terparah. Awan yang nilai temperatur puncaknya berada disekitar batas tersebut sudah dapat diidentifikasi sebagai jenis awan-awan konvektif padat (Cumulus besar atau $\mathrm{Cb}$ ). Sehingga satu jam sebelum kejadian banjir dilaporkan, diatas lokasi kejadian memang terdapat awan penghasil shower (hujan tiba-tiba) intensitas tinggi. Awan sempat berkurang pada pukul 20.00 UTC (Gambar 4(b)) yang menandakan awan sempat meluruh setelah turun hujan, dan kembali tampak pada pukul 21.00 (Gambar 4(c)) dan pukul 22.00 (Gambar 4(d)). Bahkan 2 jam setelah banjir dilaporkan, awan penghasil hujan 


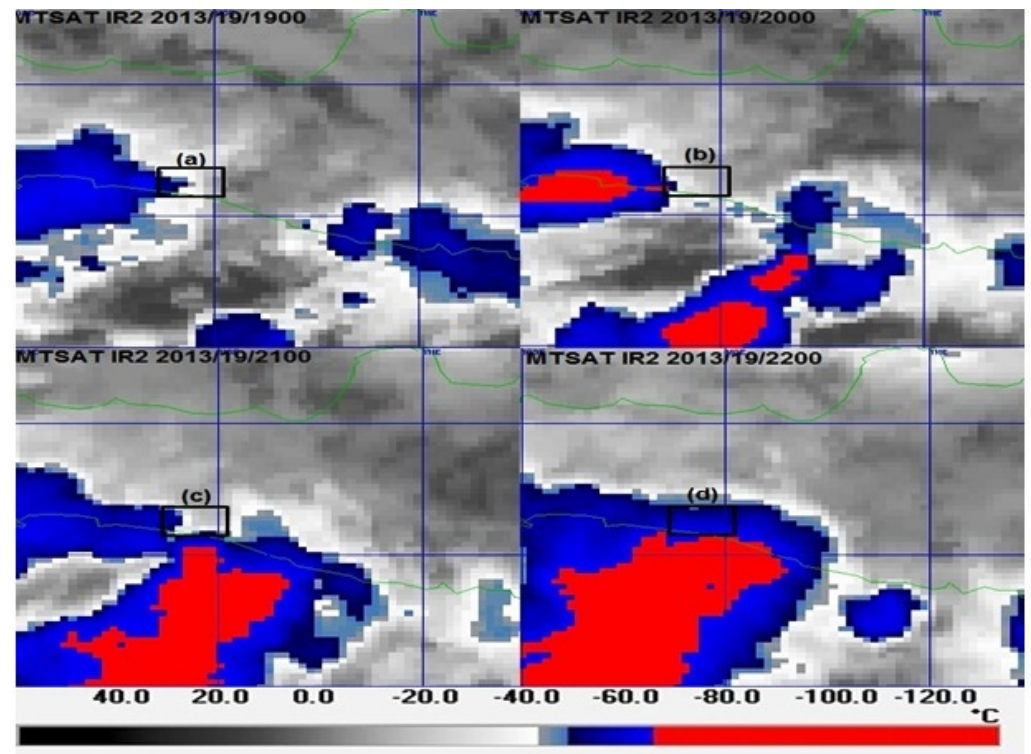

Gambar 4: Digram Alir Proses Citra Satelit MTSAT kanal IR-2, Kab. Purworejo berada pada gambar kotak hitam. (a) Citra Satelit yang diambil pada pukul 19.00 UTC, (b) diambil pada pukul 20.00 UTC, (c) diambil pada pukul 21.00 UTC, dan (d) diambil pada pukul 22.00 UTC

berangsur-angsur menutupi wilayah Kab. Purworejo. Hasil analisis dari data citra satelit ini kemudian dijadikan acuan untuk simulasi hujan menggunakan model WRF.

\section{B. Simulasi Kejadian}

\section{Plot lapisan Steering Level}

Setelah diketahui bahwa terdapat awan konvektif menjelang, ketika, dan setelah kejadian banjir, kemudian diambil plot penampang secara horisontal di lapisan $500 \mathrm{mb}$. Lapisan $500 \mathrm{mb}$ seringkali digunakan untuk merepresentasikan kondisi aliran angin udara atas. Lapisan ini dianggap bebas dari adanya efek topografi dan gesekan dari lapisan dibawahnya, selain itu lapisan $500 \mathrm{mb}$ terletak dibawah area troposfer yang lebih tinggi, dimana udara dapat mengalir dengan kencang, seperti jet stream. Sejak banyaknya sistem cuaca yang cenderung mengikuti aliran angin pada lapisan ini, maka lapisan $500 \mathrm{mb}$ sering kali dianggap sebagai lapisan pengendali (steering level) dari sistem cuaca [11].

Nilai kelembaban udara (RH) ditunjukkan oleh Gambar 5 untuk masing-masing skema pada saat menjelang (Gambar 5(a)), ketika (Gambar 5(b)), dan setelah kejadian (Gambar 5(c), (d), (e)). Secara umum nilai RH cenderung menurun pada setiap skema tiap periodenya, kecuali untuk skema New Eta Ferrier yang nilainya cenderung tetap di setiap periode, selain itu skema ini menunjukkan nilai terendah dari skema lainnya, yakni hanya pada kisaran $80-82 \%$ ketika kejadian dilaporkan. Sedang untuk vektor angin u-w, hanya output WRF6 yang berbeda dari skema lainnya. Pada lapisan ini angin vektor angin mengarah ke utara dengan kecepatan sekitar $9 \mathrm{~m} / \mathrm{s}$. Sedang untuk skema lainnya vektor angin menuju
TABEL III: Nilai indeks CAPE

\begin{tabular}{cc}
\hline \hline CAPE value (J/kg) & Atmospheric Stability \\
\hline$<0$ & Stable \\
$0-1000$ & Marginally unstable \\
$1000-2500$ & Moderately unstable \\
$2500-3500$ & Very unstable \\
$3500-4000$ & Extremely unstable \\
\hline \hline
\end{tabular}

arah barat dengan kecepatan lebih rendah yakni skitar $3 \mathrm{~m} / \mathrm{s}$. Untuk lapisan $500 \mathrm{mb}$ yang merupakan lapisan pengendali, secara umum angin seharusnya berada pada kondisi stabil dengan arah komponen-z (vektor w) terburai, yang menunjukkan adanya batas perbedaan udara masuk (konvergensi) dan udara keluar (divergensi) pada lapisan tersebut. Sehingga penggunaan skema mikrofisik untuk analisa vektor angin pada simulasi kejadian banjir ini berpengaruh terhadap analisa kecenderungan adanya pembentukan awan. Sebab komponen kecepatan angin vertikal yang rendah cenderung lebih diidentikkan dengan pertumbuhan awan.

\section{Plot penampang tegak (Vertical Velocity)}

Parameter vertical velocity (vvel) dapat difungsikan untuk mengidentifikasi pertumbuhan awan oleh karena adanya gerakan massa udara ke atas. Pada Gambar 6 vvel rata-rata bernilai positif terjadi pada lapisan $850-925 \mathrm{hPa}$, yakni sekitar 0 - 0,5 m/s pada masing-masing skema kecuali untuk skema Ferrier yang menujukkan nilai negatif di lapisan $925 \mathrm{hPa}$. Kenaikan udara ini rata-rata berlanjut sampai lapisan yang lebih tinggi sampai saat kejadian banjir terjadi. Artinya pertumbuhan awan secara vertikal cukup tinggi sebab sampai mencapai lapisan tekanan $300 \mathrm{hPa}$, nilai vvel masih positif. 


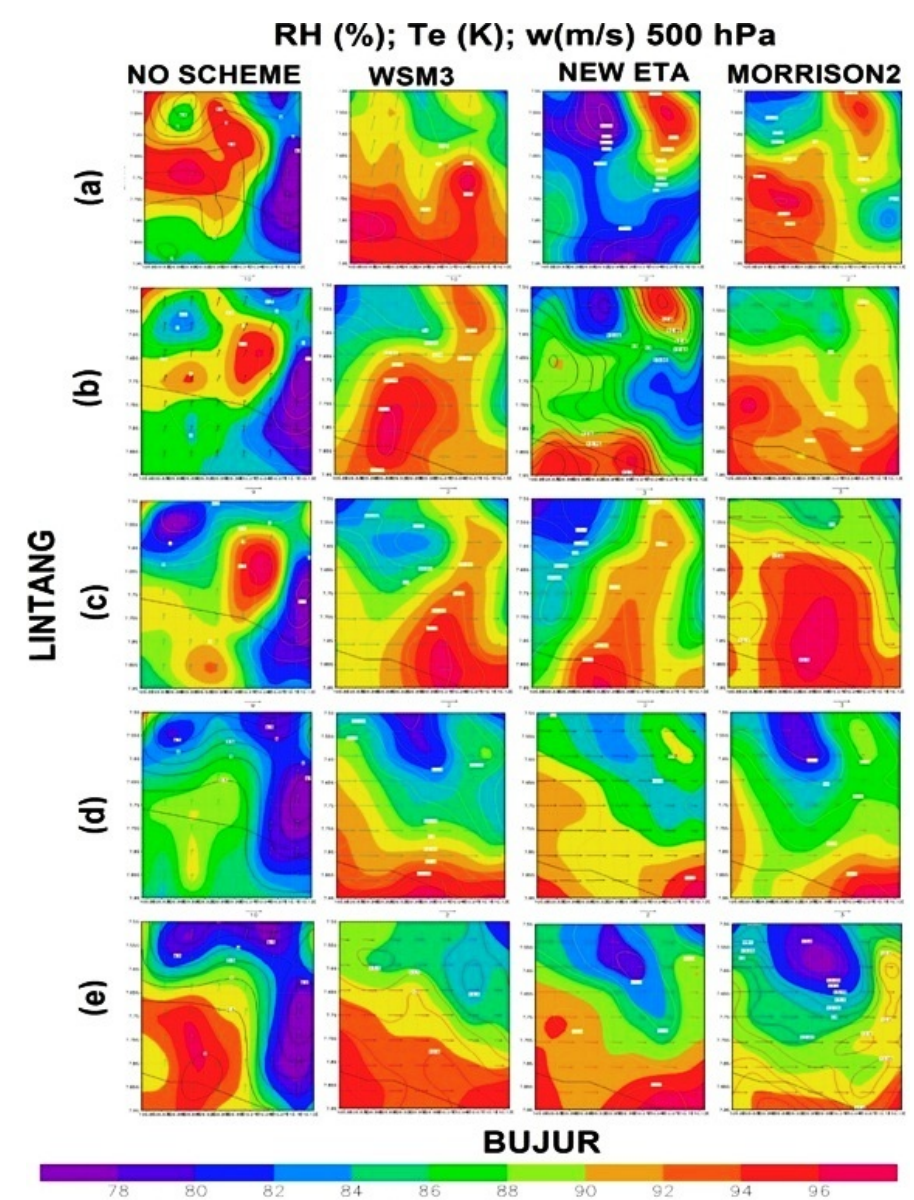

Gambar 5: Penampang lapisan $500 \mathrm{mb}$ untuk RH (shaded), angin u-w (vector), dan temperatur ekuivalen Te (contour) hasil output WRF8 pada masing-masing skema mikrofisik. (a) Tanggal 19 Desember 2013 pukul 19.00 UTC, (b) pukul 20.00 UTC, (c) pukul 21.00 UTC, (d) pukul 22.00 UTC, dan (e) pukul 23.00 UTC.
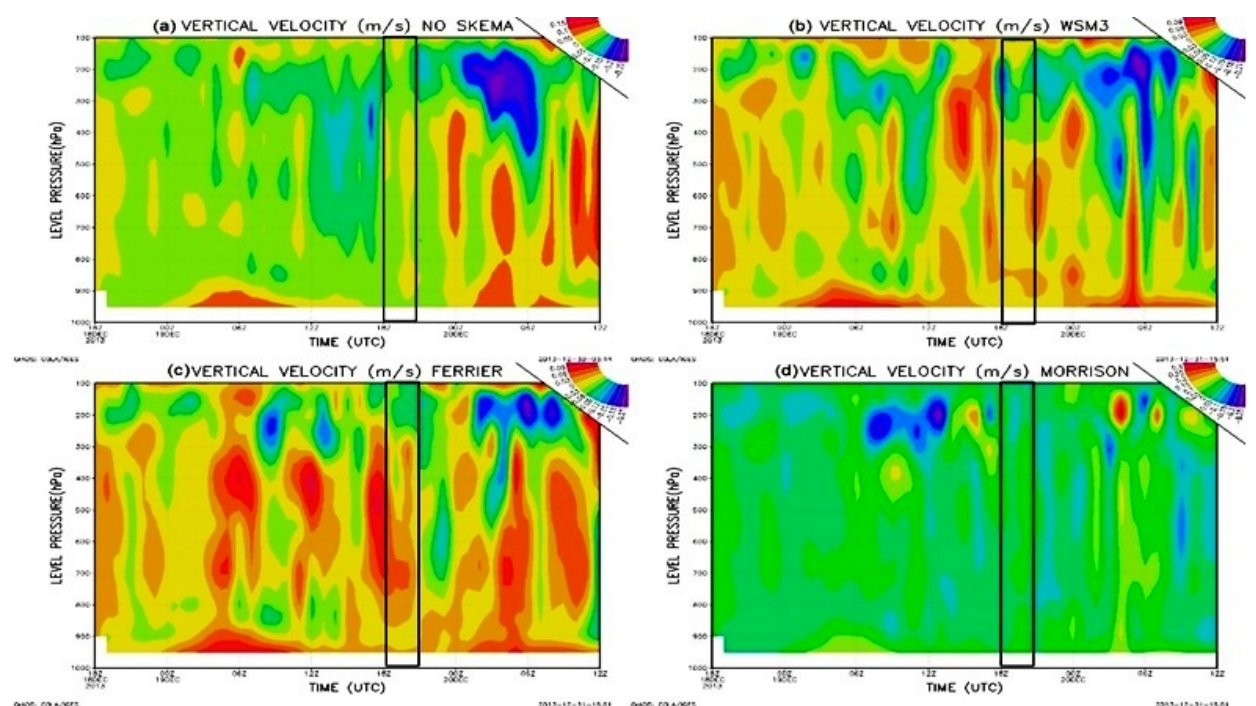

Gambar 6: Penampang tegak dari vertical velocity pada pusat lokasi kejadian berdasar ketinggian dalam lapisan tekanan hasil output WRF6 untuk (a) tanpa menggunakan skema, (b) menggunakan skama WSM3, (c) menggunakan skema New Eta Ferrier, dan (d) menggunakan skema Morrison-2. Area di dalam kotak hitam merupakan waktu menjelang sampai ketika kejadian (18.00-20.00 UTC). Positif (negatif) menunjukkan updraft (downdraft). 


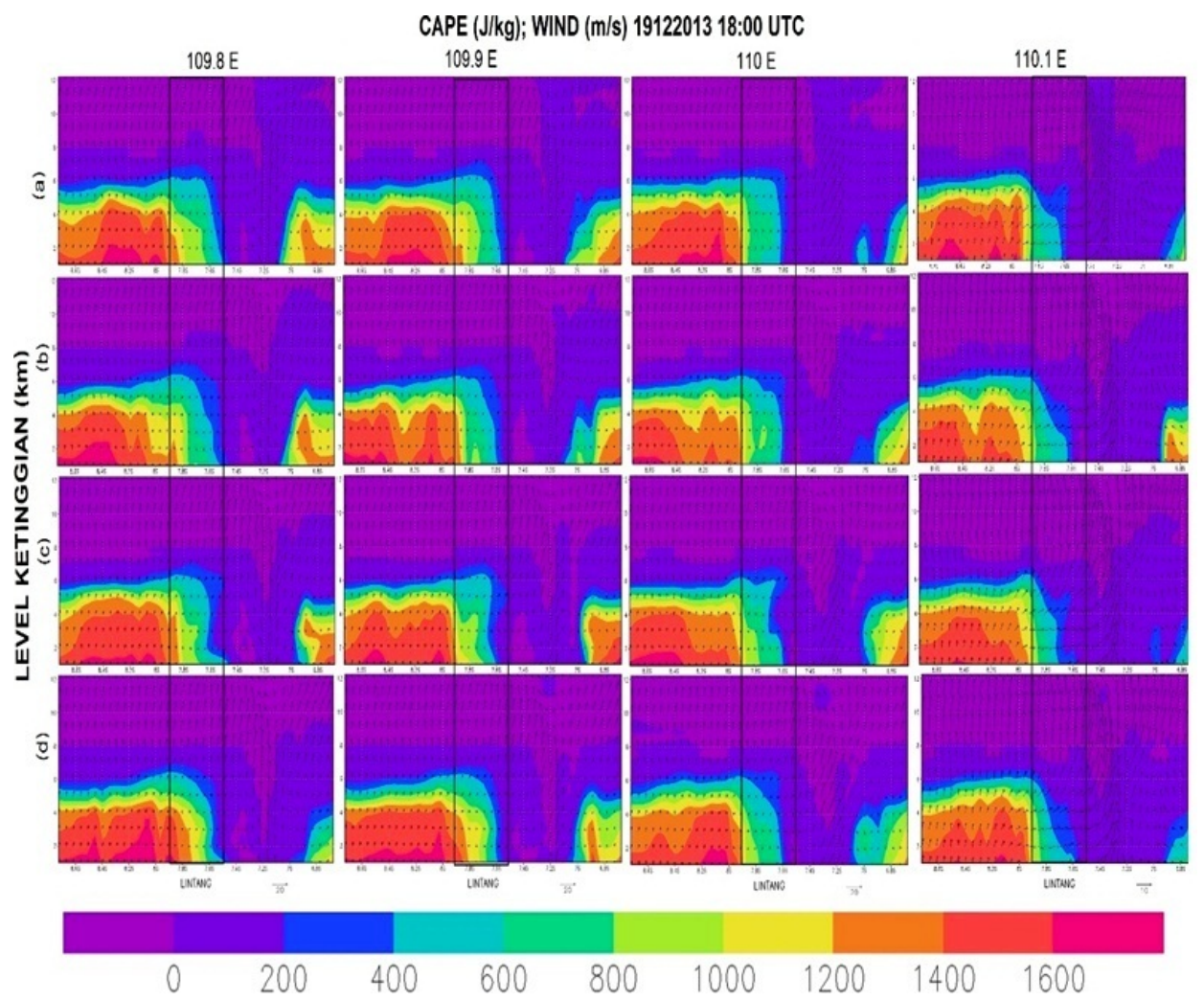

Gambar 7: Penampang vertikal (km) CAPE (shaded) dan angin (vector) di berbagai bujur dengan (a) hasil output WRF6 tanpa menggunakan skema, (b) menggunakan skema WSM3, (c) menggunakan skema New Eta Ferrison, dan (d) menggunakan skema Morrison-2. Area di dalam kotak hitam menunjukkan wilayah Kab. Purworejo secara lintang.

\section{Convective Available Potential Energy (CAPE)}

Menurut Kusumo [12], CAPE merupakan energi yang ada atau tersedia untuk konveksi. CAPE bisa disamakan dengan Positive Bouyant Energy (PBE). Kolom udara dinyatakan akan mengalami konveksi yang kuat jika nilai CAPE makin besar. Masing-masing skema menunjukkan nilai CAPE an$\operatorname{tar} 400-1200 \mathrm{~J} / \mathrm{kg}$ pada setiap bujur wilayah Kab. Purworejo. Sesuai Tabel III, CAPE dengan rentang nilai cukup besar tersebut membuktikan bahwa keadaan atmosfer menjelang kejadian banjir, yakni sekitar pukul 18.00 UTC, cenderung labil. Sehingga memungkinkan untuk parcel udara naik membawa uap air ke atas oleh adanya konveksi untuk kemudian membentuk awan-awan konvektif. Nilai CAPE bervariasi pada ketinggian antara permukaan sampai dengan $5 \mathrm{~km}$, yang merupakan rata-rata ketinggian dari awan konvektif. Pada Gambar 7 terlihat juga penampang vertikal dari vektor angin yang masing-masing menujukkan nilai kecepatan anginnya lemah, sehingga semakin memperkuat analisa adanya pertumbuhan awan konvektif penghasil hujan di lokasi kejadian banjir tersebut.

\section{Missed}

Menurut berita bahwa penyebab banjir di Kab. Purworejo tersebut merupakan adanya hujan deras disertai angin kencang. Ini dibuktikan dengan hasil observasi pos hujan pada
5 titik yang tersebar di wilayah Kab. Purworejo (Gambar 8). Hujan pada 20 Desember 2013 memiliki intensitas rata-rata $>200 \mathrm{~mm} /$ hari, sedang untuk tanggal 21 Desember intensitasnya rata-rata $>100 \mathrm{~mm} /$ hari.

Sedang hasil output model WRF6 menunjukkan memang terdapat hujan pada jam-jam tersebut di wilayah kab. Purworejo, namun intensitasnya kurang signifikan bahkan cenderung nilainya jauh dari hasil observasi, yakni nilainya $\leq 0,5$ $\mathrm{mm}$. Berdasar Gambar 9 terlihat bahwa untuk parameter hujan, skema Morrison-2 menghasilkan hujan terlebih dahulu daripada skema lainnya. Skema ini menghasilkan hujan pada 19 Desember 2013 08.00 UTC, sekitar 2 jam setelah waktu spin up. Kemudian diikuti dengan skema New Eta Ferrier bersamaan dengan skema WSM3 pada pukul 11.00 UTC namun nilainya cukup kecil yakni kurang dari $0,5 \mathrm{~mm}$. Sedang untuk hasil WRF6 tanpa menggunakan skema mikrofisik awan hujan dihasilkan pada 20 Desember 2013 pukul 03.00 UTC.

Berdasar grafik tersebut (Gambar 9) pada saat kejadian banjir maupun \pm 2 jam sebelum dan sesudah kejadian, intensitas hujan hasil output model WRF6 tidak menunjukkan nilai signifikan, sebab nilai hanya berkisar antara $0,0-0,5 \mathrm{~mm}$. Bahkan nilai hujan melonjak ketika tanggal 20 Desember 2013 pukul 03.00 UTC sampai 07.00 UTC, sekitar 7-11 jam setelah kejadian banjir. Artinya hujan hasil output WRF6 dihasilkan lebih lambat dari waktu kejadian dengan nilai cenderung lebih kecil. 


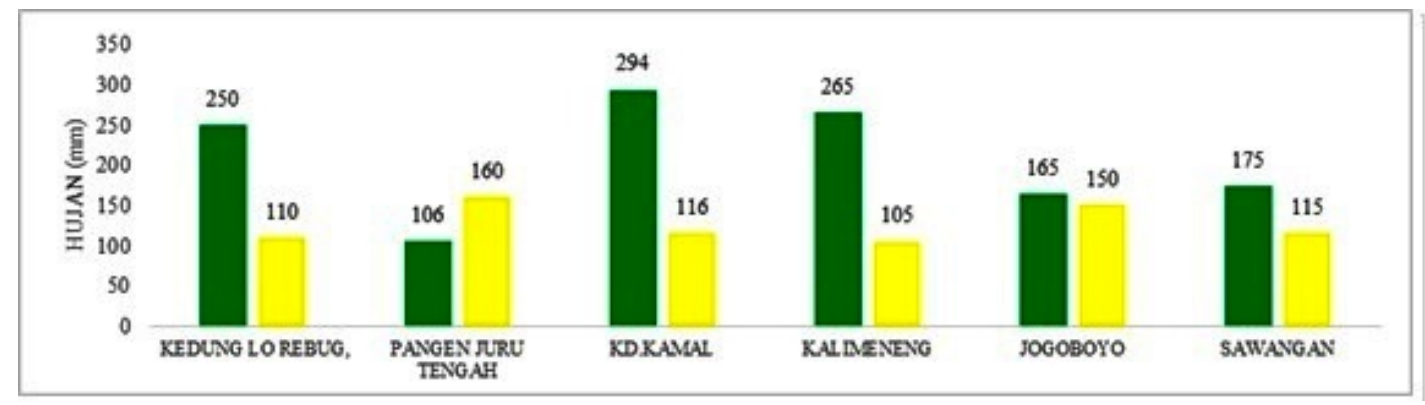

Gambar 8: Grafik observasi curah hujan 24 jam yang terukur di seluruh pos hujan di kab. Purworejo. Warna hijau merupakan nilai curah hujan yang terukur tanggal 20 Desember 2013, warna kuning untuk hasil observasi tanggal 21 Desember 2013.

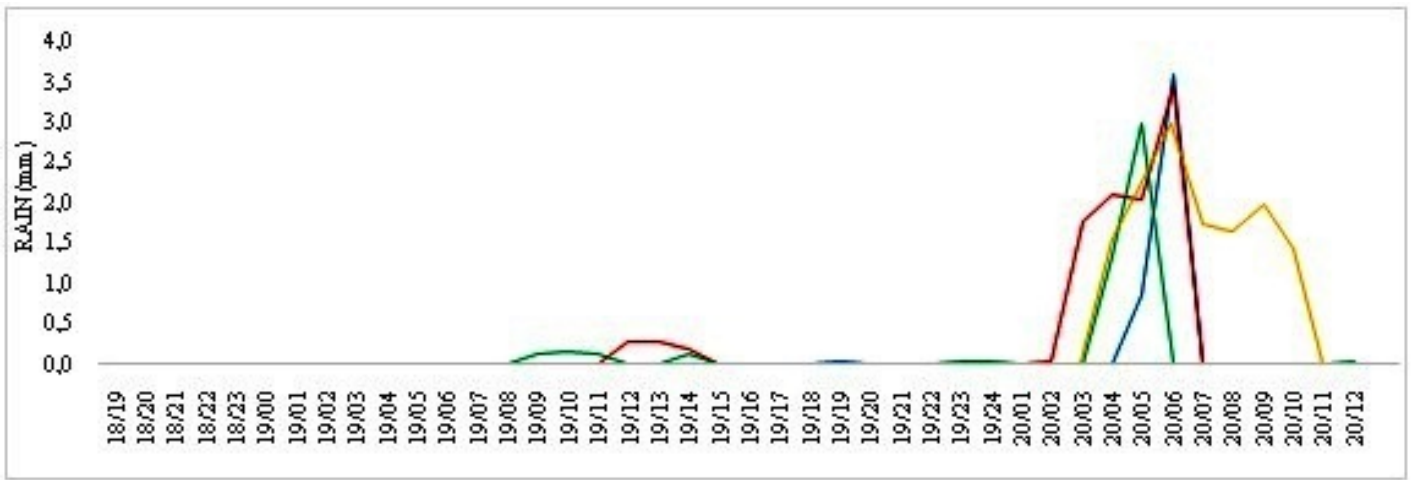

Gambar 9: Grafik Hujan hasil output model WRF6 menggunakan parameterisasi cumulus Kein-Freitsch bersama masing-masing skema mikrofisik awan, warna kuning di running tanpa skema mikrofisik, warna biru menggunakan skema WSM3, merah menggunakan skema New Eta Ferrier, dan hijau menggunakan skema Morrison-2.

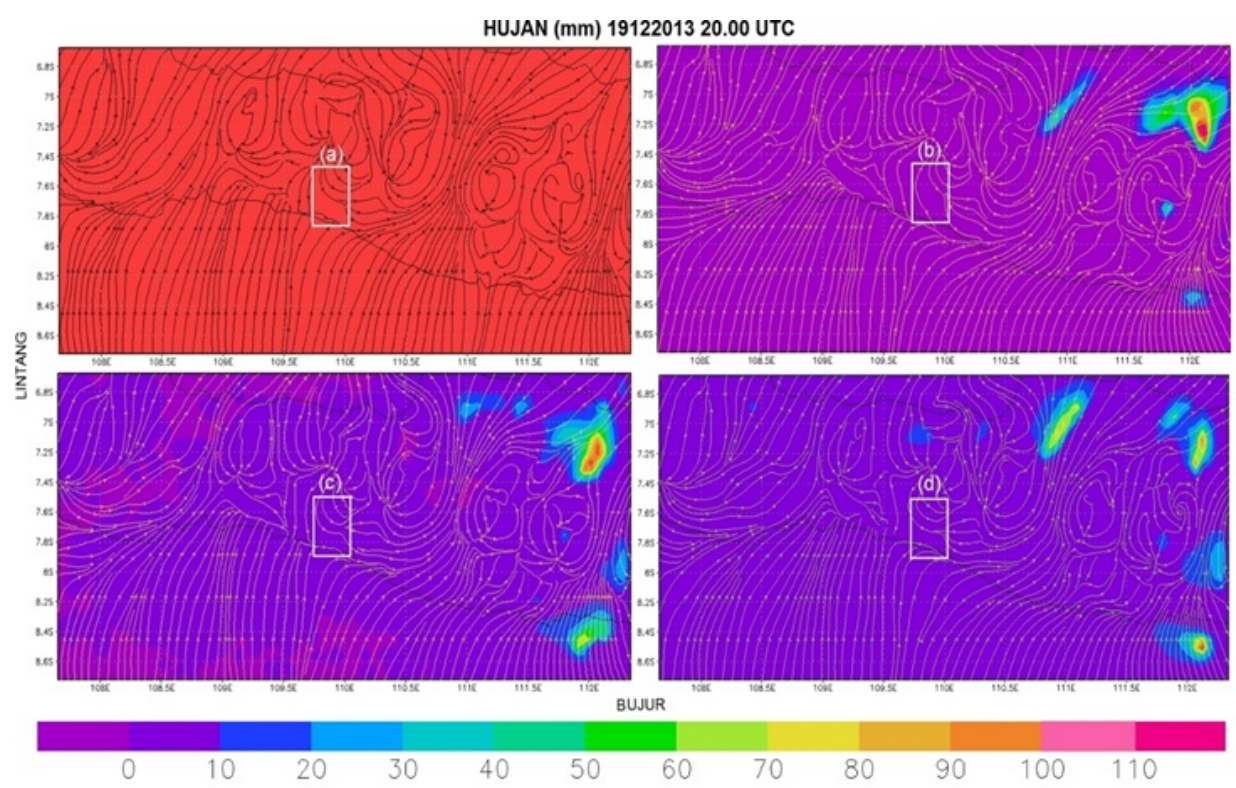

Gambar 10: Hujan hasil output WRF6 saat kejadian banjir, dimana kotak putih merupakan wilayah Kab. Purworejo. (a) Hasil output WRF6 tanpa menggunakan skema, (b) menggunakan skema WSM3, (c) menggunakan skemaNew Eta Ferrison, dan (d) menggunakan skema Morrison-2 
Hasil output hujan WRF6 untuk parameter hujan ketika terjadinya banjir Purworejo ditunjukkan oleh Gambar 10. Diketahui bahwa parameter hujan hasil WRF6 tanpa menggunakan skema parameterisasi mikrofisik tidak dapat menghasilkan hujan. Artinya penggunaan skema parameterisasi mikrofisik awan diperlukan dalam setting model WRF. Sedang untuk hasil WRF6 menggunakan parameter skema WSM3, New Eta Ferrier, dan Morrison-2, nilai hujan saat kejadian berkisar antara 0-10 mm. Artinya terdapat hujan namun nilainya sangat kecil untuk dapat menghasilkan banjir. Bahkan nilai hujan hasil WRF6 tiap skema terlihat pada jarak yang cukup jauh dari lokasi kejadian. Sedang untuk streamline angin lapisan permukaan di lokasi kejadian terdapat shearline (belokan angin) menuju daerah pertemuan angin menuju utara. Hal ini menunjukkan bahwa dari parameter angin lapisan permukaan mendukung adanya konvergensi yang diindikasikan terdapat pertumbuhan awan.

\section{SIMPULAN}

Secara keseluruhan peneliti berhasil melakukan simulasi mengenai adanya kemungkinan pertumbuhan awan konvek- tif penghasil shower (hujan tiba-tiba), baik dari parameter RH, angin, dan CAPE hasil dari output model WRF6 untuk masing-masing skema mikrofisik awan. Perbedaan penggunaan skema mikrofisik berpengaruh terhadap output model khususnya parameter hujan. Skema mikrofisik awan Morrison-2 dianggap cukup baik dalam merepserantasikan keadaan cuaca saat simulasi kejadian. Sehingga disimpulkan bahwa model mampu mensimulasikan adanya pertumbuhan awan konfektif beserta hujan yang terjadi di suatu lokasi, namun tidak cukup mampu menghasilkan intensitas hujan dan waktu sesuai yang dengan observasinya. Ketidakmampuan model dalam menghasilkan intensitas hujan yang sesuai bisa diakibatkan beberapa hal, seperti penggunaan skema parameterisasi Cumulus yang mungkin kurang sesuai,data input model yang kurang akurat, serta kurang sesuainya setting konfigurasi model dengan topografi lokasi yang menjadi domain. Penelitian lebih lanjut diharapkan dapat lebih memperbaiki hasil ini. Sebab keadaan wilayah yang menjadi domain berpengaruh terhadappengaturan setting konfigurasi model.
[1] www.bnpb.go.id

[2] D. Ridzkiana, dkk., Perbandingan skema paramaterisasi dalam simulasi cuaca numerik Menggunakan model WRF-ARW (Studi kasus hujan ekstrim Balikpapan, tanggal 5 Juli 2008), ITB, Bandung 2011.

[3] M. Rajeevan, et al., Ann Geophys, 28, 603-619 (2010).

[4] http://indonesia-peta-blogspot.com

[5] M. Santriyani, dkk., Sensitivitas parameterisasi konveksi dalam prediksi cuaca numerik menggunakan model WRF-ARW (Studi kasus hujan ekstrim di Jakarta, tanggal 7 April 2009), ITB, Bandung 2011.
[6] COMET Program, 2000.

[7] T.W. Hadi, dkk., Pelatihan Model WRF, ITB, Bandung, 2011.

[8] www.rda.ucar.edu

[9] http://satelit.bmkg.go.id

[10] Anonim, Pedoman Operasional Citra Satelit BMKG, BMKG, Jakarta, 2011.

[11] www.meteor.wisc.edu

[12] B. A. Kusumo, dkk. Simulasi fenomen Squall Line 'Sumatra' dengan Model WRF (Studi kasus pada tanggal 30 April 2007), ITB, Bandung, 2011. 